Review Article

\title{
Pre-operative Education to Reduce Anxiety: Literature Review
}

\author{
Rissa Widyasworo Hartanti $i^{1, *}$ and Lina Handayani ${ }^{1}$ \\ ${ }^{1}$ Faculty of Public Health, Universitas Ahmad Dahlan, Yogyakarta, Indonesia \\ *Correspondence: widyaswororissa@gmail.com Phone: +628562554570
}

Received 26 June 2021; Accepted 9 August 2021; Published 10 August 2021

\begin{abstract}
Background: Surgical procedure is one of the stressors that can end up with psychological disorders such as anxiety. Anxiety can lead to increased blood pressure and the risk of bleeding. Receiving detailed information on the surgical procedure is a patient's right. The information provided is expected to reduce patient anxiety and foster good relations between health workers and patients. Considering the importance of this step, we study the effect of pre-operative information before surgical procedures based on the published literature. This study aimed to summarize the previous research that elaborates on the relationship between education pre-operative and anxiety.
\end{abstract}

Method: A literature review was used in this study. Google Scholar, PubMed, and ProQuest databases were chosen as data sources. We sough article published during 2016-2021. In total, 450 articles were screened using inclusion and exclusion criteria for analysis.

Results: Eight articles reported that there was an effect of education on patient anxiety.

Conclusion: Providing education is an effective approach to reduce patient anxiety.

Keywords: Education; Patient; Anxiety; Information

\section{INTRODUCTION}

Surgery is an invasive treatment action that displays body parts, makes an incision, then repairs and closes the wound with suturing (1). Surgery is a high-risk action that requires an operating room to minimize infection during surgery (2). The stages of surgery start from preoperative, intraoperative, and post-operative. Pre-operative preparation is one of the phases that determines the success of the surgery. Pre-operative preparation starts from the patient entering the treatment room until the patient arrives in the operating room (3). The readiness of the patient includes physical and mental readiness. Physical readiness examines physical health, nutritional, fluid, and electrolyte balance, gastric and colonic hygiene, personal hygiene, and bladder emptying. Mental/psychic pre-operation readiness is psychological readiness in dealing with surgery. Patients who do not have mental readiness will experience anxiety before surgery (4). Anxiety also has medical risks such as increased 
breathing, vasoconstriction of blood vessels, increased blood pressure which causes surgical bleeding. Several reasons can cause pre-operative anxiety, including fear of physical changes, uncertainty, surgery pain, death risk (5).

The prevalence of anxiety disorder worldwide varies 2.5 to 7 percent by country (6). It is estimated that globally 284 million people experienced an anxiety disorder in 2017 . About 63 percent (179 million) are women, and 105 million are men. According to a survey in the United States, $18.1 \%$ or about 42 million people live with anxiety (7). In Indonesia, the results of Basic Health Research 2018 show that $6,2 \%$ of people aged 15-24 years and 15.941-157.695 people in Indonesia experience anxiety (8). Causes of anxiety such as potential stressors, knowledge, social support, environmental adaptation process, and operating experience influence patient anxiety (9). To make s surgical procedure successful need psychology preparations cover the patients. Patients need to be educated, and all treatment alternatives should be explained (10). Mental or psychological support is required for patients who experience anxiety by providing information about the surgery to be conducted. Providing details on operating time, information on the operation site's situation or things experienced during the surgical procedure can reduce anxiety and make the patient more prepared to undergo surgical procedures. The role of the nurse as an advisor is vital to perform these actions (4). Accordingly, we want to know the effect of pre-surgery education on patient anxiety patients. This paper aims to summarize the previous research that elaborates on the relationship between education pre-operative and anxiety.

\section{METHOD}

\section{Search Strategy}

This literature study searched research articles in reputable databases such as PubMed, ProQuest, and Google Scholar. A set of keywords, namely "education pre-surgery," "patient anxiety," "effect of education," and "effect of pre-surgery education," were used to search for articles. Title, keywords, abstracts, language, year of published and method were screened for the first step for relevant articles. In the second step, we screened the article according to the relevant variable, and last we selected the article based on the full-text availability. Figure 1 shows the flow chart of the article review employed in this paper.

\section{Inclusion and Exclusion Criteria}

In our analysis, the article should fulfill the following inclusion criteria: article published in English or Indonesian, the article discussed Indonesia or globally, published 2016-2021, abstract and the full text is freely accessible, the research sample was elective surgery patient (planned surgery). While the exclusion criteria were qualitative research, the article did not mention the instrument used for measuring anxiety, study in the emergency setting, full text not freely available.

\section{RESULTS}

Based on the results of a literature search, eight articles were found that matched the criteria. The research article identifies patient education and anxiety in various hospitals in Indonesia and outside Indonesia. Eight articles were published as review articles, five from Indonesia, and three journals were published outside Indonesia (Polandia, Iran, and 
Taiwan). The most significant number of samples used was 213 , and the smallest number of samples was 15. A research instrument is a tool used to collect or obtain data in conducting research. A total of 3 articles used State-Trait Anxiety Inventory (STAI) anxiety instrument, three articles used the HARS (Hamilton Anxiety Rating Scale) instrument, 1 article used Zung Self-Rating Anxiety Scale (SAS/ZRAS), and 1 article used T-MAS.

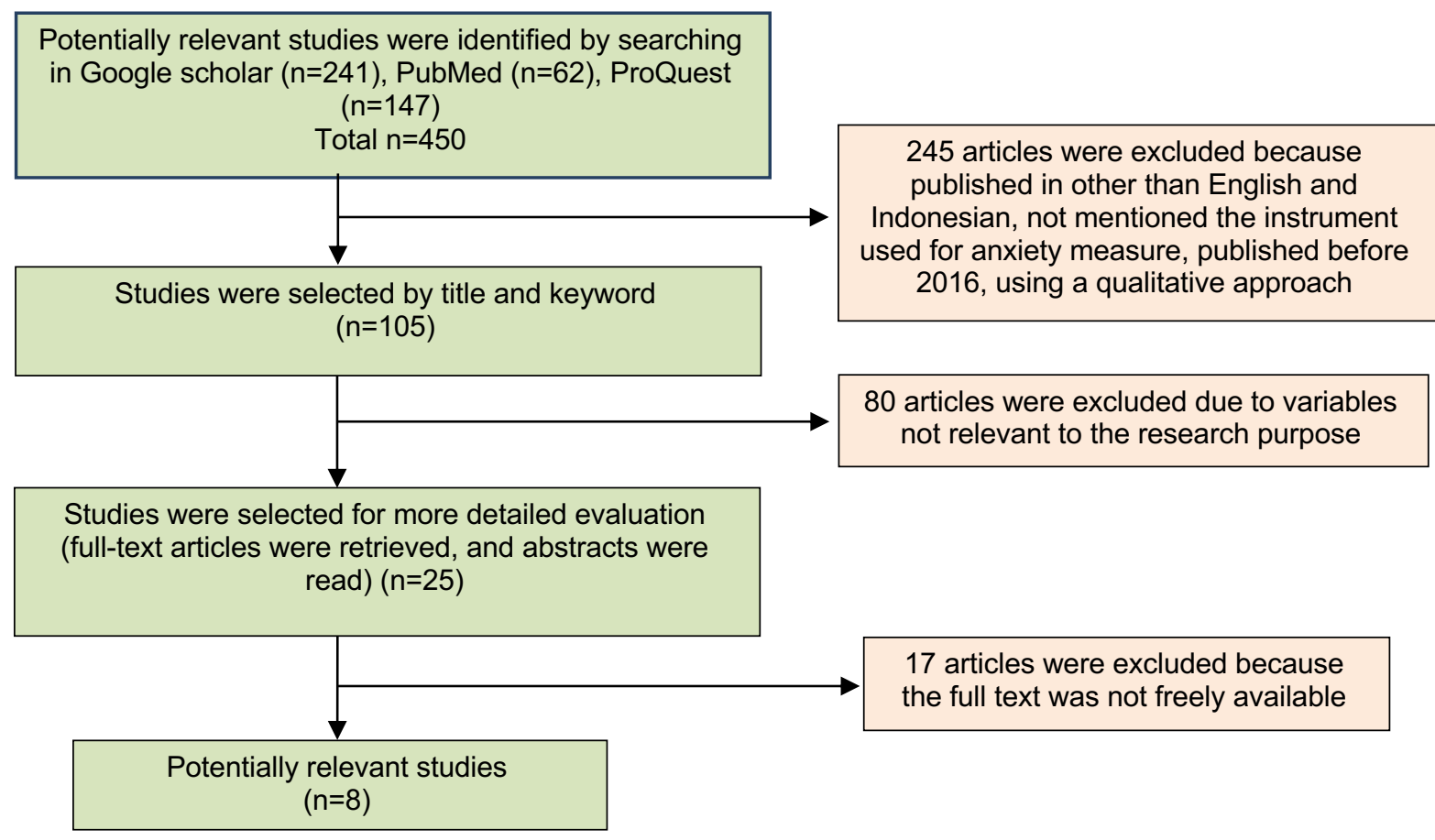

Figure 1. The flow chart of the article review

There are differences in the research design used, 6 studies using quasi-experiments and 2 studies using pre-experiments. All articles explain that educating and providing information to patients can reduce patient anxiety. We found that five articles using Wilcoxon signedrank test, and three studies using the T-test for analysis purposes. All articles explained that educating and providing information to patients before getting an operation can reduce patient anxiety.

Table 1. Literature search synthesis

\begin{tabular}{|c|c|c|c|c|c|}
\hline No & $\begin{array}{c}\text { Title, } \\
\text { Author }\end{array}$ & Method & Sample & $\begin{array}{l}\text { Instrument and } \\
\text { analysis used. }\end{array}$ & Result \\
\hline 1 & $\begin{array}{l}\text { The Effect of } \\
\text { Health } \\
\text { Education on } \\
\text { Changes in } \\
\text { Anxiety of Pre } \\
\text { Elective Surgery } \\
\text { Patients in } 3^{\text {rd }} \\
\text { Class of RSUD } \\
\text { City of Madiun } \\
\text { Widyaningrum. } \\
\text { (2017) }\end{array}$ & $\begin{array}{l}\text { Pre- } \\
\text { experiment }\end{array}$ & $\begin{array}{l}\text { The number of } \\
\text { samples was } 35 \\
\text { respondents, one } \\
\text { group without } \\
\text { control by } \\
\text { consecutive } \\
\text { sampling. }\end{array}$ & $\begin{array}{l}\text { Data collection } \\
\text { used Zung Self- } \\
\text { Rating Anxiety } \\
\text { Scale (ZSAS) } \\
\text { Data were } \\
\text { analyzed using } \\
\text { a T-test }\end{array}$ & $\begin{array}{l}\text { Before being given health } \\
\text { education, the average } \\
\text { anxiety level of respondents } \\
\text { was in the moderate } \\
\text { anxiety category, } 24 \\
\text { respondents }(68.6 \%) \text {. After } \\
\text { being given health } \\
\text { education, most of the } \\
\text { respondents' anxiety levels } \\
\text { were in the non-anxious } \\
\text { category were } 19 \\
\text { respondents (54.3\%). } \\
\text { Statistical test results show } \\
\text { p-value = } 0.000 \text { (p-value< = } \\
0.05 \text { ), there is an effect of } \\
\text { education in patients with }\end{array}$ \\
\hline
\end{tabular}




\begin{tabular}{|c|c|c|c|c|c|}
\hline No & $\begin{array}{c}\text { Title, } \\
\text { Author }\end{array}$ & Method & Sample & $\begin{array}{l}\text { Instrument and } \\
\text { analysis used. }\end{array}$ & Result \\
\hline & & & & & $\begin{array}{l}\text { pre-elective surgery in 3rd } \\
\text { Class of General Hospital } \\
\text { of Madiun District. }\end{array}$ \\
\hline 2 & $\begin{array}{l}\text { Effect of an } \\
\text { Orientation Tour } \\
\text { on Preoperative } \\
\text { Anxiety in } \\
\text { Candidates for } \\
\text { Coronary Artery } \\
\text { Bypass Grafting: } \\
\text { A Randomized } \\
\text { Clinical Trial } \\
\\
\text { Reyhaneh } \\
\text { Niknejad, } \\
\text { Mohsen } \\
\text { Mirmohammad } \\
\text { Sadeghi, } \\
\text { Mohammad } \\
\text { Akbari, Ahmad } \\
\text { Ghadami (2019) }\end{array}$ & $\begin{array}{l}\text { Quasi } \\
\text { Experiment }\end{array}$ & $\begin{array}{l}\text { The number of } \\
\text { samples is } 70 \\
\text { (control group= } 35 \\
\text { Respondens and } \\
\text { intervention group= } \\
35 \text { respondents), } \\
\text { randomized clinical } \\
\text { trial study. }\end{array}$ & $\begin{array}{l}\text { Anxiety } \\
\text { instrument with } \\
\text { State-Trait } \\
\text { Anxiety } \\
\text { Inventory(STAI) } \\
\text { Data was } \\
\text { analyzed using } \\
\text { T-test. }\end{array}$ & $\begin{array}{l}\text { Anxiety levels were } \\
\text { significantly lower in the } \\
\text { intervention group }(35.40 \pm \\
10.24) \text { compared to the } \\
\text { control group }(46.91 \pm 9.51) \\
(P<0.001) \text {. So the pre- } \\
\text { operative orientation } \\
\text { overview has a positive } \\
\text { impact on the anxiety level } \\
\text { of the prospective CABG } \\
\text { patient. }\end{array}$ \\
\hline 3 & $\begin{array}{l}\text { The Effect of } \\
\text { Health } \\
\text { Education on } \\
\text { Anxiety Levels } \\
\text { in Pre-Major } \\
\text { Surgery Patients } \\
\text { Fadli, Irmayanti, } \\
\text { Kassaming, } \\
\text { (2019) }\end{array}$ & $\begin{array}{l}\text { Quasi } \\
\text { experiment }\end{array}$ & $\begin{array}{l}\text { The number of } \\
\text { samples is } 15 \\
\text { respondents, one } \\
\text { group without } \\
\text { control by purposive } \\
\text { sampling. }\end{array}$ & $\begin{array}{l}\text { Anxiety } \\
\text { instruments with } \\
\text { HARS (Hamilton } \\
\text { Anxiety Rating } \\
\text { Scale). Wilcoxon } \\
\text { signed-rank test } \\
\text { was used to } \\
\text { analyze the } \\
\text { data. }\end{array}$ & $\begin{array}{l}\text { There was a significant } \\
\text { change in the average level } \\
\text { of anxiety before and after } \\
\text { health education to patients } \\
\text { with pre-major surgery } \\
\text { ( } 23.67 \text { to } 17.93 \text { ). So the } \\
\text { average difference before } \\
\text { and after is } 5.73 \text {. The } \\
\text { results showed } p=0.001 \text {. } \\
\text { So there is deferent before } \\
\text { and after education, it can } \\
\text { be concluded that there is a } \\
\text { significant effect of health } \\
\text { education on reducing the } \\
\text { level of anxiety in pre-major } \\
\text { surgery }\end{array}$ \\
\hline 4. & $\begin{array}{l}\text { Influence of Pre- } \\
\text { operative } \\
\text { Information } \\
\text { Support On } \\
\text { Anxiety, Pain, } \\
\text { and Satisfaction } \\
\text { with post- } \\
\text { operative } \\
\text { analgesia in } \\
\text { children and } \\
\text { adolescents } \\
\text { after thoracic } \\
\text { surgery: a } \\
\text { randomized, } \\
\text { double-blind } \\
\text { study } \\
\text { Lucyna } \\
\text { Tomaszek, } \\
\text { Grazyna } \\
\text { Cepuch, Dariusz } \\
\text { Fenikowski } \\
\text { (2018) }\end{array}$ & $\begin{array}{l}\text { Quasi- } \\
\text { experiment }\end{array}$ & $\begin{array}{l}\text { The number of } \\
\text { samples is } 112 \\
\text { consist control } \\
\text { group subjects=56 } \\
\text { who the nurse gave } \\
\text { routine pre- } \\
\text { operative } \\
\text { information, and the } \\
\text { experimental } \\
\text { group=56 offered } \\
\text { additional } \\
\text { psychological } \\
\text { consultation by } \\
\text { randomized, double- } \\
\text { blind study. }\end{array}$ & $\begin{array}{l}\text { Anxiety } \\
\text { instrument with } \\
\text { State-Trait } \\
\text { Anxiety } \\
\text { Inventory } \\
\text { (STAI). Wilcoxon } \\
\text { signed-rank test } \\
\text { was used to } \\
\text { analyze the } \\
\text { data. }\end{array}$ & $\begin{array}{l}\text { In the experiment group, } \\
\text { the level of state anxiety } 48 \\
\text { hours post-surgery was } \\
\text { significantly lower, }<7 / 10 \\
\text { sten to the procedure. In } \\
\text { the control group, the level } \\
\text { of post-operative anxiety } \\
\text { was substantially higher } \geq 7 \\
\text { sten to the procedure. So, } \\
\text { information support } \\
\text { psychologists before } \\
\text { thoracic surgery reduce } \\
\text { post-operative anxiety } \\
\text { levels. }\end{array}$ \\
\hline 5. & $\begin{array}{l}\text { The Effect of } \\
\text { Health } \\
\text { Education on } \\
\text { Preoperative } \\
\text { Physical } \\
\text { Preparation in }\end{array}$ & $\begin{array}{l}\text { This } \\
\text { research } \\
\text { used Quasi } \\
\text { experiment }\end{array}$ & $\begin{array}{l}\text { The number of } \\
\text { samples in this } \\
\text { study amounted to } \\
32 \text { consists } 16 \\
\text { respondents as } \\
\text { intervention group }\end{array}$ & $\begin{array}{l}\text { Questionnaire } \\
\text { used T-MAS. } \\
\text { Data were } \\
\text { analyzed using } \\
\text { Wilcoxon } \\
\text { signed-rank test }\end{array}$ & $\begin{array}{l}\text { There is a different level of } \\
\text { anxiety in the treatment } \\
\text { group and control group p- } \\
\text { value: } 0.00 \text { ( } p \text {-value }<0.05 \text { ), } \\
\text { meaning the effect of health } \\
\text { education about physical }\end{array}$ \\
\hline
\end{tabular}




\begin{tabular}{|c|c|c|c|c|c|}
\hline No & $\begin{array}{l}\text { Title, } \\
\text { Author }\end{array}$ & Method & Sample & $\begin{array}{l}\text { Instrument and } \\
\text { analysis used. }\end{array}$ & Result \\
\hline & $\begin{array}{l}\text { Reducing } \\
\text { Anxiety in } \\
\text { Hernia Patients } \\
\text { Puspita, } \\
\text { Miftahus (2017) }\end{array}$ & & $\begin{array}{l}\text { and } 16 \text { respondents } \\
\text { as control groups by } \\
\text { consecutive } \\
\text { sampling approach. }\end{array}$ & $\begin{array}{l}\text { and the Mann } \\
\text { Whitney test. }\end{array}$ & $\begin{array}{l}\text { preparation on anxiety in } \\
\text { hernia patients. }\end{array}$ \\
\hline 6. & $\begin{array}{l}\text { The Effect of } \\
\text { Cardiac Pre- } \\
\text { Catheterization } \\
\text { Health } \\
\text { Education on } \\
\text { Patient Anxiety } \\
\text { Levels at the } \\
\text { Cardiac Service } \\
\text { Installation } \\
\text { Lily Misriani, } \\
\text { Feriana Ira, } \\
\text { Agnis (2020) }\end{array}$ & $\begin{array}{l}\text { This study } \\
\text { used a pre- } \\
\text { experiment }\end{array}$ & $\begin{array}{l}\text { The number of } \\
\text { samples is } 16 \\
\text { respondents. one } \\
\text { group without } \\
\text { control by purposive } \\
\text { sampling approach. }\end{array}$ & $\begin{array}{l}\text { Anxiety } \\
\text { instrument with } \\
\text { HARS (Hamilton } \\
\text { Anxiety Rating } \\
\text { Scale) } \\
\text { questionnaire. } \\
\text { Data were } \\
\text { analyzed using } \\
\text { Wilcoxon } \\
\text { signed-rank test. }\end{array}$ & $\begin{array}{l}\text { The result shows anxiety } \\
\text { before being given health } \\
\text { education was severe } \\
\text { anxiety }(19 \%) \text {, moderate } \\
\text { anxiety }(62 \%) \text {, mild anxiety } \\
(19 \%) \text {, whereas after health } \\
\text { education, it became mild } \\
\text { anxiety }(75 \%) \text { and no } \\
\text { anxiety }(25 \%) \text {. A P-value of } \\
0.0001(<0.05) \text { means } \\
\text { providing cardiac pre- } \\
\text { catheterization health } \\
\text { education on the patient's } \\
\text { anxiety level. }\end{array}$ \\
\hline 7. & $\begin{array}{l}\text { The Effect } \\
\text { Health } \\
\text { Education Using } \\
\text { The Leaflet } \\
\text { Media Reduce } \\
\text { Anxiety Levels } \\
\text { In Pre } \\
\text { Operations } \\
\text { Fitria Anisa,Mugi } \\
\text { Hartoyo,Sudiart } \\
\text { o (2019) }\end{array}$ & $\begin{array}{l}\text { This study } \\
\text { used a } \\
\text { quasi- } \\
\text { experiment }\end{array}$ & $\begin{array}{l}\text { The number of } \\
\text { samples is } 30 \\
\text { respondents } \\
\text { consisting of } 15 \\
\text { respondents in the } \\
\text { intervention group } \\
\text { and } 15 \text { respondents } \\
\text { in the control group } \\
\text { by consecutive } \\
\text { sampling approach. }\end{array}$ & $\begin{array}{l}\text { The anxiety } \\
\text { questionnaire } \\
\text { used HARS } \\
\text { (Hamilton } \\
\text { Anxiety Rating } \\
\text { Scale). Data } \\
\text { were analyzed } \\
\text { using Wilcoxon } \\
\text { signed-rank test. }\end{array}$ & $\begin{array}{l}\text { The result showed an effect } \\
\text { of health education using } \\
\text { media leaflets on the level } \\
\text { of anxiety ( } p=0.001) \text {. The } \\
\text { post-test score of the } \\
\text { intervention group was } \\
9.13 \text {, and the control group } \\
15.27 \text {, meaning health } \\
\text { education with leaflets can } \\
\text { reduce anxiety. }\end{array}$ \\
\hline 8. & $\begin{array}{l}\text { A Study on the } \\
\text { Effects of a } \\
\text { Health } \\
\text { Education } \\
\text { Intervention on } \\
\text { Anxiety and } \\
\text { Pain During } \\
\text { Colonoscopy } \\
\text { Procedures } \\
\text { Feng-Chi Hsueh } \\
\text { \& Chih-Mei } \\
\text { Chen \& Chien- } \\
\text { An Sun \& Yu- } \\
\text { Ching Chou } \\
\text { Szu-Mei Hsiao \& } \\
\text { Tsan Yang, } \\
\text { (2016) }\end{array}$ & $\begin{array}{l}\text { This study } \\
\text { used a } \\
\text { quasi- } \\
\text { experiment }\end{array}$ & $\begin{array}{l}\text { The study sample } \\
\text { was } 213 \text { consist of } \\
103 \text { patients in the } \\
\text { intervention group } \\
\text { and } 110 \text { in the } \\
\text { control group. }\end{array}$ & $\begin{array}{l}\text { The } \\
\text { questionnaire } \\
\text { used a } \\
\text { questionnaire } \\
\text { State-Trait } \\
\text { Anxiety } \\
\text { Inventory } \\
\text { (STAI). } \\
\text { Data were } \\
\text { analyzed using a } \\
\text { T-test. }\end{array}$ & $\begin{array}{l}\text { The anxiety score in the } \\
\text { intervention group before } \\
\text { health education was } 48.7 \\
\pm 11.6 \text { and after health } \\
\text { education } 39.2 \pm 8.7 \text {. This } \\
\text { study shows that } \\
\text { multimedia health } \\
\text { information about } \\
\text { colonoscopy procedures } \\
\text { effectively reduces anxiety } \\
\text { and pain in colonoscopy } \\
\text { patients. }\end{array}$ \\
\hline
\end{tabular}

\section{DISCUSSION}

The education program is vital in the pre-operative period. It is one of the alternative programs that can reduce patient anxiety (11). Anxiety mostly comes from operation effects; therefore, increasing patients' pre-operative education can relieve their anxiety and stabilize their emotions (12). Mental intervention in pre-operative patients can relax, promote the operation's success, improve the recovery and finally improve patients and their families (9).

According to the analysis, almost all of the articles report that education effectively reduces anxiety before surgery. In Madiun regional hospital, the study followed the research expectations; health education can decrease anxiety patients. Communication is established 
between health workers and patients, so health education makes the patient feel cared (13). In coronary artery bypass grafting, patients with intervention had significantly lower anxiety than other groups without orientation. The reason is that the patients who participated in orientation education before surgery became familiar with operating room conditions, which helps them adapt to the new environment and feel secure. Health education had positive effects on anxiety in coronary artery bypass grafting candidates. It can be used effective technique for relieving anxiety (14). Primary surgery patients show that health education with leaflets can reduce anxiety. Health education intervention was succeeding. A patient who experienced severe anxiety became anxiety mildly, felt moderate anxiety became mild anxiety and felt mild anxiety became less anxiety (15).

At the thoracic surgery, the previous study showed that the patient whose preparation for surgery needs the information to support psychology. These results advocated training for the nurse to provide individually tailored information support to patients before thoraces surgery. Patients with elevated levels of trait anxiety should be identified before surgery, and offers a dedicated educational program to prepare them for the surgical procedure adequately tho their emotional status (16). Previous research mentioned that health education affects the anxiety of hernia surgery patients. Health education is one of the nonmedical therapies that reduce pre-operative anxiety. Education intervention is an additional intervention, especially for nurses, in reducing patient anxiety (17). According to Masriani's research, the result showed an effect of health education on the anxiety level of pre-cardiac catheterization patients at the hearth service installation in Syaiful Anwar hospital. Health education is an effort to change the respondent's behavior, including change in thinking and acting to reduce anxiety. The research found an anxiety decrease after received health education (18).

Rizki found that there was an effect of health education with leaflet media. The intervention group has been shown to decrease anxiety compared to before the health education was given. The provision of health education using leaflet media can be used as an alternative for presenting information to prepare patients before surgery to decrease anxiety levels (19). Hence, Hsueh stated that education is necessary for patients with a certain characteristic. Medical staff may design multiple healthcare programs for a patient with different characteristics. This study showed that multimedia health information about colonoscopy procedures effectively reduces anxiety and pain in colonoscopy patients (20).

\section{CONCLUSION}

Anxiety is an unpleasant psychological condition caused by the surgery that the patient will experience. Non-pharmacological interventions with comprehensive and structured education can be applied as an intervention to reduce patient anxiety. Providing education and adequate information is effective in reducing patient anxiety.

\section{Authors' contribution}

RWH was responsible for research design, data collection, analysis, and drafting the first manuscript. LH monitored the research course and reviewed the manuscript. 


\section{Funding}

This research has not received external funding

\section{Conflict of interest}

There is no conflict of interest in this research.

\section{REFERENCES}

1. Apriansyah A, Romadoni S, Andrianovita D. The relationship between the level of preoperative anxiety with the degree of pain in post-section caesarian patients. J Keperawatan Sriwij. 2015;2(1):1-9. [in Bahasa]

2. Sutoto. National Standard for Hospital Accreditation. Garna PH, editor. Jakarta Selatan: Komisi Akreditasi Rumah Sakit (KARS); 2017. 162 p. [in Bahasa]

3. Kurniawan A, Kurnia E, Triyoga A. Preoperative patient knowledge in surgical preparation. J Penelit Keperawatan. 2018;4(2). [in Bahasa]

4. Majid A. Perioperative Nursing. Yogyakarta: Gosyen Publishing; 2011. [in Bahasa]

5. Maryunani A. Perioperative Nursing. Jakarta Timur: Trans Info Media; 2014. [in Bahasa]

6. Ritchie H. Mental Health - Our World in Data [Internet]. 2018 [cited 2021 Jun 25]. Available from: https://ourworldindata.org/mental-health

7. Blvd W, Arlington. Anxiety Disorders [Internet]. 2021 [cited 2021 Aug 9]. Available from: https://www.nami.org/About-Mental-IIIness/Mental-Health-Conditions/Anxiety-Disorders

8. The Indonesia Ministry of Health. National Basic Health Research Report [Internet]. Jakarta; 2018 [cited 2021 Aug 10]. Available from: http://labdata.litbang.kemkes.go.id/images/download/laporan/RKD/2018/Laporan_Nasio nal RKD2018 FINAL.pdf

9. Sari YP, Riasmini NM, Guslinda. Analysis of factors associated with patient anxiety levels pre-major surgery in Space Teratai. Menara IImu. 2020; XIV(02):133-47. [in Bahasa]

10. Al-Abbadi HA, Basharaheel HA, Alharbi MR, Alharbi HA, Sindi D, Bamatraf M. Patients' perspectives of surgical safety before and after their elective Surgeries at King Abdulaziz University Hospital, Jeddah, Saudi Arabia. Cureus. 2019;11(11).

11. Sari YK, Widayati A, Prayogi B. The effectiveness of counseling of thinking, feeling and acting (TFA) approach to blood pressure in patients with pre cataract surgery. $J$ Ners dan Kebidanan (Journal Ners Midwifery). 2018 Aug;5(2):090-6. [in Bahasa]

12. Chabibi M, Purwanti E, Novyriana E. The Relationship of Nurse Therapeutic Communication on Preoperative Patient Satisfaction at the Central Surgical Installation of PKU Muhammadiyah Hospital Gombong. In: Proceeding of The URECOL: The 10th University Research Colloqium 2019 Sekolah Tinggi IImu Kesehatan Muhammadiyah Gombong Hubungan. Gombong: URECOL; 2019. p. 464-72. Available from: http://repository.urecol.org/index.php/proceeding/article/view/677/660 [in Bahasa]

13. Widyaningrum DA. The effect of health education on changes in anxiety of pre-elective patients in 3rd class of RSUD Kota Madiun. War Bhakti Husada Mulia J Kesehat. 2017;4(1). [in Bahasa]

14. Niknejad R, Mirmohammad-Sadeghi M, Akbari M, Ghadami A. Effects of an orientation tour on pre-operative anxiety in candidates for coronary artery bypass grafting: A randomized clinical trial. ARYA Atheroscler. 2019;15(4):154-60.

15. Fadli, Toalib I, Kassaming. The effect of health education on anxiety levels in pre-major surgery patients. J IIm Kesehat Diagnosis Vol. 2017;13(6):1-5. [in Bahasa]

16. Tomaszek L, Cepuch G, Fenikowski D. Influence of pre-operative information support on anxiety, pain and satisfaction with post-operative analgesia in children and adolescents after thoracic surgery: A randomized double-blind study. Biomed Pap. 2019;163(2):172-8.

17. Aryani HP, Shomad M. The Effect of Health Education on Preoperative Physical 
Preparation in Reducing Anxiety HerniaPatient. J Keperawatan dan Kebidanan. 2017 Aug;9(2):6-6.

18. Masriani L, Handian FI, Kristiana AS. The effect of providing cardiac pre-catheterization health education on the patient's level of anxiety in cardiac service installations. J IIm Kesehat Media Husada. 2020 Apr;9(1):28-35. [in Bahasa]

19. Annisa Rizki F, Hartoyo M, Sudiarto. Health education using the leaflet media reduce anxiety levels in pre-operation patients. Jendela Nurs J. 2019;3(1):49-57.

20. Hsueh FC, Chen CM, Sun CA, Chou YC, Hsiao SM, Yang T. A Study on the Effects of a Health Education Intervention on Anxiety and Pain during Colonoscopy Procedures. J Nurs Res. 2016 Jun;24(2):181-9. 